\title{
TA7
}

W34m no. A-97-4

c. 2

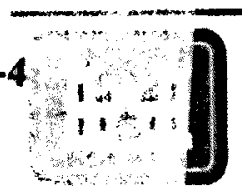

US Army Corps of Engineers

Waterways Experiment Station
Miscellaneous Paper A-97-4 June 1997
US-CE-C Property of the

United States Government

Aquatic Plant Control Research Program

\section{Seasonal Biomass and Carbohydrate Allocation in a Southern Population of Eurasian Watermilfoil}

by John D. Madsen

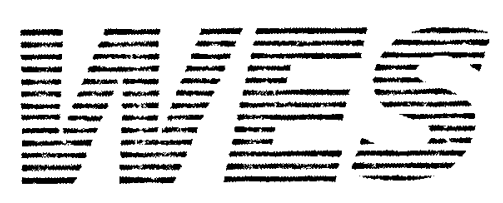

Approved For Public Release; Distribution Is Unlimited
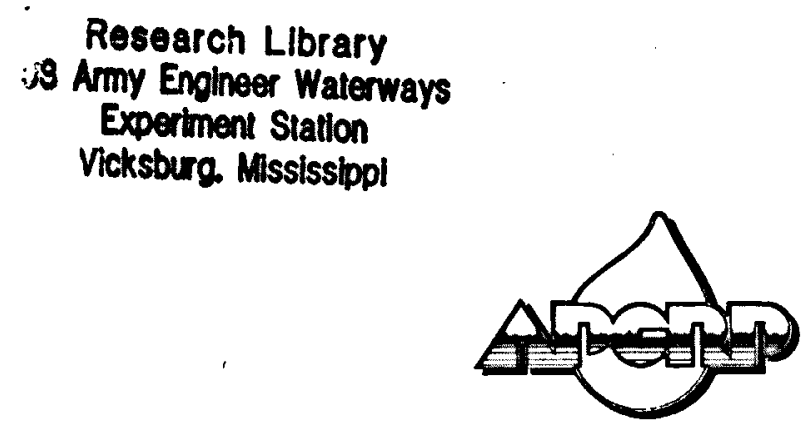

Prepared for Headquarters, U.S. Army Corps of Engineers 


\section{Seasonal Biomass and Carbohydrate Allocation in a Southern Population of Eurasian Watermilfoil}

by John D. Madsen

U.S. Army Corps of Engineers

Waterways Experiment Station

3909 Halls Ferry Road

Vicksburg, MS 39180-6199

Final report

Approved for public release; distribution is unlimited 


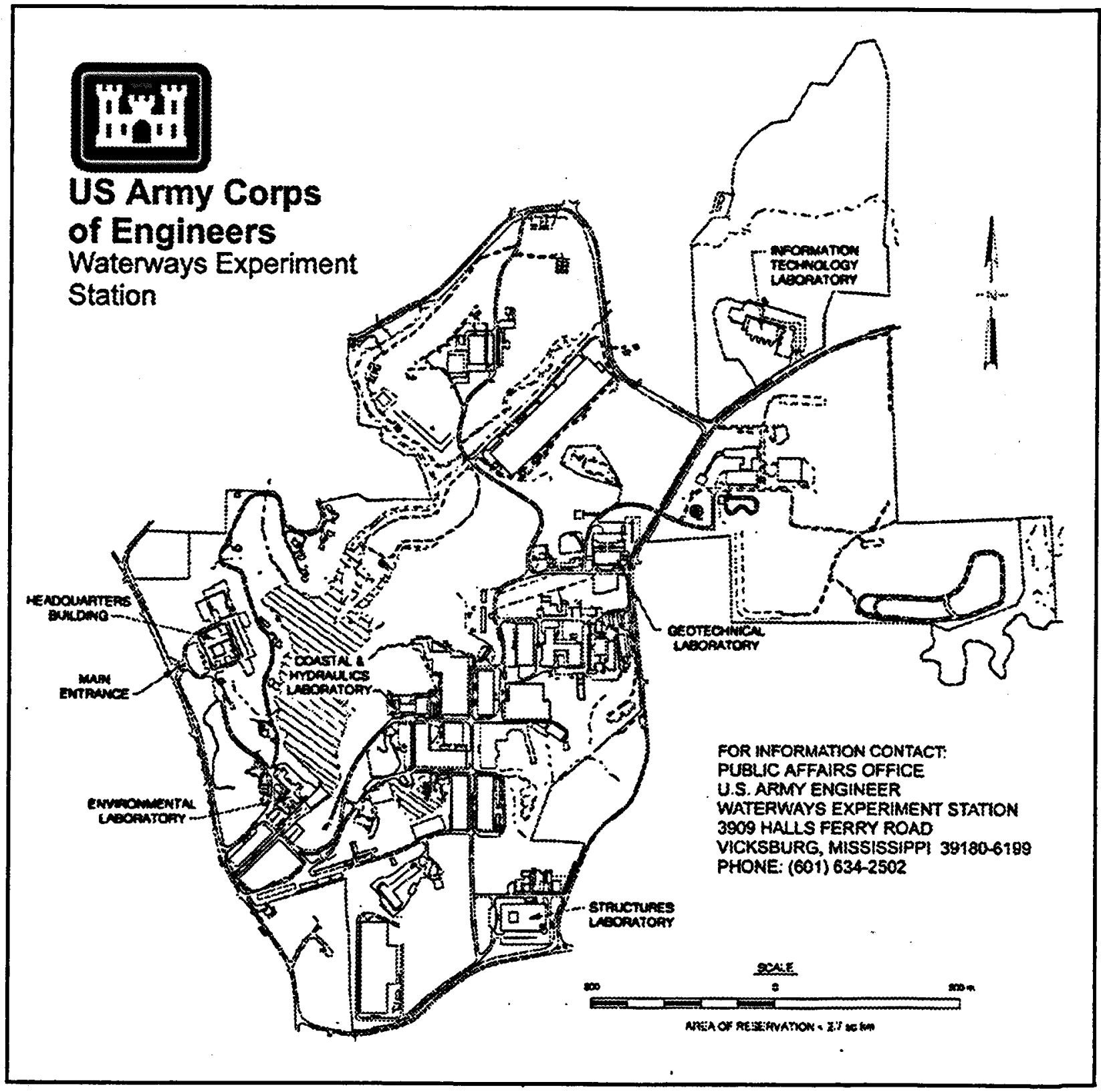

Waterways Experiment Station Cataloging-in-Publication Data

Madsen, John Douglas.

Seasonal biomass and carbohydrate allocation in a southern population of Eurasian watermilfoil / by John D. Madsen ; prepared for U.S. Army Corps of Engineers.

13 p. : ill. ; $28 \mathrm{~cm}$. - (Miscellaneous paper ; A-97-4)

Includes bibliographic references.

1. Aquatic weeds - Development. 2. Aquatic plants - Control. 3. Eurasian watermilfoil Growth. 4. Eurasian watermilfoil - Seasonal variations. I. United States. Army. Corps of Engineers. II. U.S. Army Engineer Waterways Experiment Station. . III. Aquatic Plant Control Research Program (U.S. Army Engineer Waterways Experiment Station) IV. Title. V. Series: Miscellaneous paper (U.S. Army Engineer Waterways Experiment Station) ; A-97-4.

TA7 W34m no.A-97-4 


\section{Preface}

The work reported herein was conducted as part of the Aquatic Plant Control Research Program (APCRP), Work Unit 32441. The APCRP is sponsored by the Headquarters, U.S. Army Corps of Engineers (HQUSACE), and is assigned to the U.S. Army Engineer Waterways Experiment Station (WES) under the purview of the Environmental Laboratory (EL). Funding was provided under Department of the Army Appropriation No. 96X3122, Construction General. The APCRP is managed under the Center for Aquatic Plant Research and Technology (CAPRT), Dr. John W. Barko, Director. Mr. Robert C. Gunkel was Assistant Director for the CAPRT. Program Monitor during this study was Ms. Denise White, HQUSACE.

The Principal Investigator for the study was Dr. John D. Madsen, Ecosystem Processes and Effects Branch (EPEB), Environmental Processes and Effects Division (EPED), EL, WES. The study was conducted and report prepared by Dr. Madsen. Field assistance at the Lewisville Aquatic Ecosystem Research Facility was provided by Chetta Owens, AScI Corporation, and Ms. Bekah Westover, Ms. Nicole Flint, Ms. Brittany Glassie, Mr. Timothy Irby, Ms. Lovely John, Mr. Keith Lloyd, Ms. Diane Smith, Ms. Melissa Smith, and Mr. Nathan Standifer, all of EPEB. Laboratory analyses were performed at WES by Mses. Jane Brazil, Margaret Richmond, and Anne Stewart, all of AScI Corporation, and Dr. Susan Sprecher, EPEB. Drs. Kurt Getsinger and Susan Sprecher, both of EPEB, provided technical reviews for this report. Results of this study were first published as an article in the Journal of Aquatic Plant Management (Vol 35, 1997), reprints of which were provided for use in preparation of this report.

The investigation was performed under the general supervision of Dr. John Harrison, Director, EL; and Dr. Richard E. Price, Chief, EPED.

At the time of publication of this report, Director of WES was Dr. Robert W. Whalin. Commander was COL Bruce K. Howard, EN. 
This report should be cited as follows:

Madsen, J. D. (1997). "Seasonal biomass and carbohydrate allocation in a southern population of Eurasian watermilfoil," Miscellaneous Paper A-97-4, U.S. Army Engineer Waterways Experiment Station, Vicksburg, MS. 


\title{
Seasonal Biomass and Carbohydrate Allocation in a Southern Population of Eurasian Watermilfoil
}

\author{
JOHN D. MADSEN'
}

\begin{abstract}
Seasonal biomass and carbohydrate allocation patterns of Eurasian watermilfoil (Myriophyllum spicatum L.) were evaluated to elucidate potential points in the seasonal phenological cycle for improved control. Eurasian watermilfoil was sampled from outdoor 0.3 ha ponds in Lewisville, TX from January 1991 to December 1993 and analyzed for free sugars, starch and total nonstructural carbohydrates (TNC). Root crowns stored up to $30 \% \mathrm{TNC}$, followed by autofragments $(25 \%)$, lower stems $(22 \%)$, and upper stems and inflorescences $(12 \%)$. Low levels of stored carbohydrates occurred in July (1991), April (1992), and May (1993). Low levels of stored carbohydrates also were observed in October for all three years. Low points in carbohydrate storage might be exploited to improve management of Eurasian watermilfoil.

Key words: Myriophyllum spicatum, phenology, starch, total nonstructural carbohydrate, autofragment, inflorescence.
\end{abstract}

\section{INTRODUCTION}

Perennial plants of the temperate zone typically store carbohydrates as starch in roots, rhizomes, and specialized structures (e.g., tubers) during late summer and autumn, for winter survival and regrowth in spring (McAllister and Haderlie 1985, Cyr et al. 1990). Without these reserves, the plant may not be able to survive winter or to reestablish growth in the spring. Management of terrestrial weed species has exploited this knowledge, either by repetitive mowing to reduce stored carbohydrates (Klingman et al. 1975) or by timing herbicide applications to coincide with periods of low starch reserves (Schirman and Buchholtz 1966).

Aquatic plants have many structures for storing starch or other nonstructural carbohydrates (TNC) for overwintering or regrowth; including roots (Garza et al. 1994), rhizomes (Gallagher et al. 1984), stems (Best 1977), stembases in rosette species (Tucker and DeBusk 1981), tubers (Hodgson 1966), winter buds (Titus and Adams 1979), and turions (Winston and Gorham 1979). In most aquatic macrophytes, a distinct seasonal cycle is observed in which carbohydrate storage reaches a peak in late summer or fall and is depleted as spring regrowth occurs (Madsen 1991). The typical cycle can be disrupted through disturbance, stress and herbivory.

\footnotetext{
'Research Biologist, U.S. Army Engineer Waterways Experiment Station, Attn: CEWES-ES-P, 3909 Halls Ferry Rd., Vicksburg, MS 39180-6199. Submitted for publication November 6, 1995 and in revised form June 27, 1996.
}

A knowledge of carbohydrate storage has proven beneficial in previous aquatic plant management applications. For instance, several studies of harvesting effects on Eurasian watermilfoil have examined carbohydrate depletion to predict long-term success of harvest operations (Kimbel and Carpenter 1981, Perkins and Sytsma 1987, Painter and Waltho 1985, Painter 1988). Herbicide treatments were found to be more effective when applied at times of lower carbohydrate storage in alligatorweed (Weldon and Blackburn 1968) and sago pondweed (Hodgson 1966). Feeding of Neochetina weevils on waterhyacinth leaves reduced leaf carbohydrate content, even at low densities (Center and Van 1989). Thus, the effectiveness of some biological, chemical and mechanical control techniques on aquatic plants might be interpreted by their effects on whole plant carbohydrate storage.

Eurasian watermilfoil (Myriophyllum spicatum L.) is a herbaceous perennial submersed aquatic plant that grows in water from $0.3 \mathrm{~m}$ to $7 \mathrm{~m}$, most commonly in the $1 \mathrm{~m}$ to $3 \mathrm{~m}$ water depth interval (Aiken et al. 1979). A native of Eurasia, it was simultaneously introduced to four states in the 1940's (Couch and Nelson 1985). Eurasian watermilfoil has been documented as occurring in thirty-seven of the United States and three Canadian provinces (Engel 1993). Eurasian watermilfoil is highly adventive and productive, resulting in rapid spread and dense monospecific growths (Grace and Wetzel 1978 , Smith and Barko 1990). Vegetative propagation is predominantly via self-formed stem segments (or autofragments) produced through the development of an abscission layer (Madsen et al. 1988). Dense monospecific stands not only create a nuisance to humans for flood control, navigation, and recreation, but also displace native vegetation, causing declines-in native species -abundance and diversity (Madsen et al. 1991).

A better understanding of the seasonal cycles of plants might produce insight into the timing of biological, herbicidal and mechanical control techniques, to maximize their effectiveness. Specifically, management techniques timed to coincide with reductions in stored carbohydrates may reduce the ability of the target plant to regrow after treatment, or to survive an overwintering period.

The goals of this study were to 1) identify the seasonal dynamics of biomass and carbohydrate allocation patterns of Eurasian watermilfoil, and 2) use those carbohydrate allocation patterns to identify periods of low carbohydrate levels in the annual cycle of the plant at one geographical location. 


\section{MATERIALS AND METHODS}

Outdoor experimental ponds with a surface area of 0.3 ha were used at the Lewisville Aquatic Ecosystem Research Facility (LAERF) near Lewisville, TX (latitude $33^{\circ} 04^{\prime} 45^{\prime \prime} \mathrm{N}$, longitude $\left.96^{\circ} 57^{\prime} 30^{\prime \prime} \mathrm{W}\right)$. Average pond depth was $1.0 \mathrm{~m}$, with a maximum depth of $1.5 \mathrm{~m}$ (Smart et al. 1995). Meteorological data was monitored continuously using an Omnidata Easylogger (Omnidata Corp., Logan, UT) and thermistors to record air and pond water temperature every 5 minutes, with hourly averages.

During 1991, twelve biomass samples were collected each month from one pond. During 1992 and 1993, two ponds were utilized. Samples were collected every six weeks from October through March, and every three weeks from April through September. Six samples were collected per pond in 1992, and twelve samples per pond in 1993. Biomass samples were collected in a random pattern, with a $0.1 \mathrm{~m}^{2}$ quadrat. Samples were consistently collected between $10 \mathrm{am}$ and $2 \mathrm{pm}$ during sample days.

Biomass samples were separated into root crowns, upper and lower shoots, autofragments, and inflorescences. Upper and lower shoots were separated at one-half the height of the total shoot. Root crowns, shoots, autofragments and inflorescences were also counted. Samples were dried at $55 \mathrm{C}$ in a forced air oven for at least 48 hours before weighing. Dried samples were ground in a Cyclone mill to pass a $1 \mathrm{~mm}$ mesh filter prior to analysis.

A minimum of at least six replicates per plant part were analyzed for each sample time. Plant samples were analyzed for TNC using a modification by Swank et al. (1982). Extracts of TNC (starch, hydrolyzable sugars, reducing sugars) were incubated for 15 minutes at $55 \mathrm{C}$ with one unit of amyloglucosidase (Sigma A-3042) per milliliter of extractant to completely hydrolyze starch before assaying for reducing sugars (Nelson 1944). Free sugars were determined on extracts not incubated with amyloglucosidase. Starch content was calculated from TNC and sugar content.

\section{RESULTS AND DISCUSSION}

Biomass allocation. Total biomass values for 1991 do not show any distinct pattern, but in both 1992 and 1993 peak biomass was observed in May (Figure 1B), which is substantially earlier than observed for northern populations such as Lake Wingra, WI (Adams and McCracken 1974) or Lake Washington, WA (Perkins and Sytsma 1987). Peak biomass was followed by-senescence,-with the annual biomass minima observed in August of each year; northern populations such as Lake Washington, WA (Perkins and Sytsma 1987) or Buckhorn Lake, ONT (Painter 1988) typically are at or near their biomass peak during late summer. A midsummer biomass minimum may be due to the combination of normal postflowering senescence and high water temperatures typical of shallow ponds in Texas (Figure 1A). Eurasian watermilfoil has a relatively high temperature optima $(25-30 \mathrm{C})$ for temperate aquatic plants (Grace and Wetzel 1978), but does not appear to tolerate daily maximum water temperatures that may reach $35 \mathrm{C}$, as has been observed for these ponds (Smart et al. 1995). Significant leaf senescence was also observed in midsummer, which may be a symptom of temperature stress.

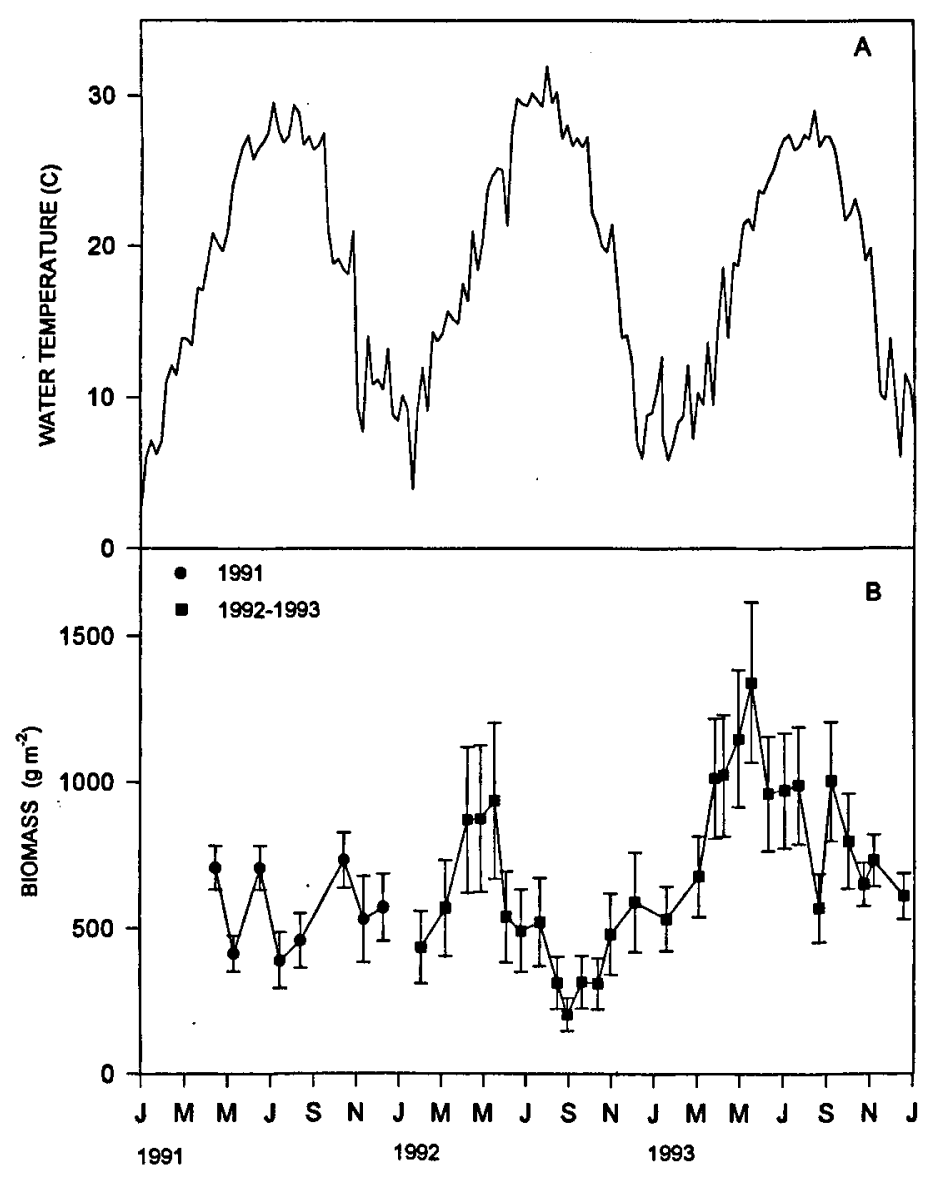

Figure 1. A) Average water temperature (C) in experimental ponds in Lewisville, TX from 1991 to 1993; and B) total Eurasian watermilfoil biomass $\left(\mathrm{g} \mathrm{m}^{2}\right)$ in experimental ponds in Lewisville, TX from 1991 to 1993. Bars indicated \pm 1 standard error of the mean.

Regrowth initiates in September, slows or even decreases slightly during midwinter (December to February), and then increases again in March.

Biomass allocation to various plant components also followed distinct seasonal patterns (Figure 2). Although a small amount of flowering occurred throughout spring and early summer, the most pronounced peaks appeared in June and October of each year (Figure 2A). This peak preceded the period of greatest senescence each year. Coinciding with, or slightly later than, the flowering peak each year was a peak in autofragment production (Figure 2B).

Upper stem, or canopy, biomass increases each spring to a peak in May, then decreased as autofragmentation occurred and senescence began (Figure 2C). Autofragments are formed entirely in the upper canopy, their production significantly reduced upper stem biomass. The lower stems are largely unaffected by autofragment formation, so the percent allocation of biomass to lower stems and root crown appears to increase. Lower stem biomass reached an earlier peak, in February or March, but also reached a minimum in August (Figure 2D). This earlier peak may be related to reallocation of carbohydrates during spring regrowth, and production of new branches and buds. Root crown biomass exhibited peak biomass in May and December for both 1992 

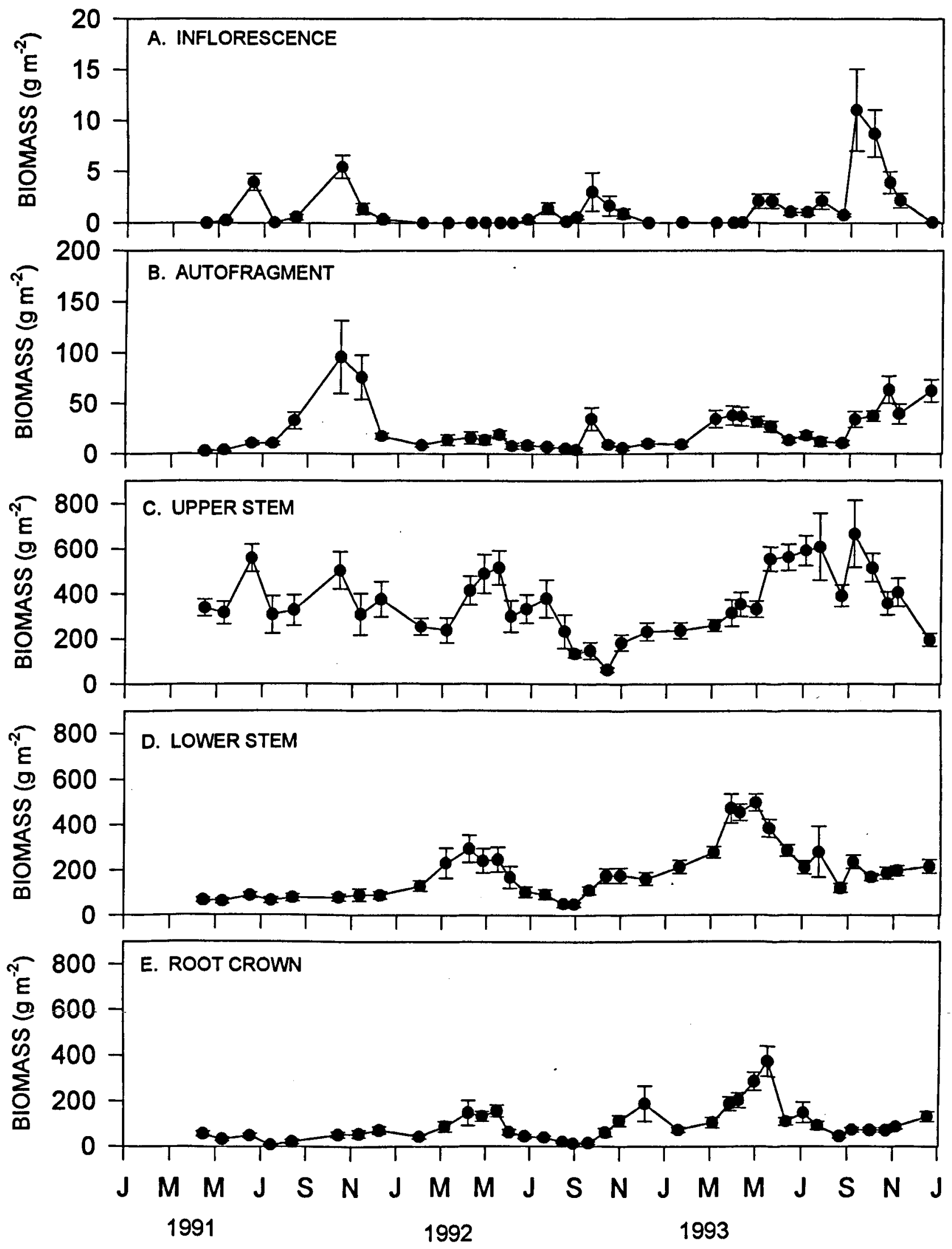

Figure 2. Eurasian watermilfoil plant component allocation, biomass $\left(\mathrm{g} \mathrm{m}^{-2}\right)$, in experimental ponds at Lewisville, TX from 1991 to 1993 . A) Inflorescences, B) Autofragments, C) Upper stem, D) Lower stem, E) Root crown. Bars indicated \pm 1 standard error of the mean. 
and 1993. This may be related to high TNC levels and the production of new root buds and spread of the plant vegetatively during the winter and early spring in this locality (Madsen, unpubl. data).

Biomass allocation can also be expressed as a percentage of total biomass. Eurasian watermilfoil, like many perennial submersed aquatic plants, allocates very little to sexual propagation (Madsen 1991). In the Texas populations, maximum allocation to sexual propagation was less than $1 \%$. In contrast, allocation to autofragments, which are the primary vegetative form of propagation, was as high as $11 \%$. Overwintering was predominantly as root crowns (10 to $22 \%$ ), and lower shoots (15 to $45 \%$ ). Upper shoots ranged from $20 \%$ (winter) to $75 \%$ (summer) of total biomass.

Carbohydrate Allocation. Plant components varied greatly in proportions and total amounts of carbohydrates, and in seasonal allocation patterns (Figure 3). Inflorescences (Figure $3 \mathrm{~A}$ ) had high amounts of free sugars (up to $5 \%$ ), and usually an equivalent amount of starch. Autofragments also had high concentrations of sugars (5\% or more), but also large stored concentrations of starch (up to $15 \%$ ), for TNC concentrations of up to $25 \%$ (Figure $3 \mathrm{~B}$ ). The storage of large quantities of starch in stem autofragments indicated these are stems adapted for propagation, not simply accidental breakage of the stem. Autofragments detach from the stem following formation of an abscission zone, frequently forming adventitious roots, and are specifically produced for vegetative propagation of this species (Patten 1956, Aiken et al. 1979). Autofragments, which typically have more than twice the concentration of TNC than allofragments (formed through breakage due to an external force), are significantly more likely to overwinter successfully and are less likely to die during the growing season than are allofragments (Kimbel 1982).

Upper stem tissues typically had less than $5 \%$ reducing sugars and a comparable amount of starch for TNC levels of up to $10 \%$ (Figure 3C). Maximum levels of TNC in upper and lower stems appeared to occur in midsummer, at the same approximate times as root crown minima of TNC.

Lower stem carbohydrate concentrations varied widely over the year (Figure 3D). Lower stems not only stored large amounts of starch (up to $15 \%$ ), but the highest levels of reducing sugars for all plant components appeared in these tissues during the time carbohydrates were being reallocated from the root crown to upper stems during rapid growth in the spring and early summer.

Root crown tissues are the main storage area for carbohydrates in overwintering Eurasian watermilfoil. Starch concentrations can reach $20 \%$, with TNC concentrations of up to $30 \%$ (Figure $3 \mathrm{E}$ ). Total nonstructural carbohydrate concentrations consistently reached a peak in January or February. Springtime minima varied from April through July of the three study years. Although root crowns are not specialized for storage, they can hold a significant reserve of carbohydrates for regrowth. In studying sympatric populations of water celery (Vallisneria americana L.) and Eurasian watermilfoil in Lake Wingra, Titus and Adams (1979) found that water celery winter bud TNC levels could reach $46 \%$, as compared to Eurasian watermilfoil root crown TNC concentrations of $25 \%$. However, water celery winter bud biomass was only $18 \mathrm{~g} \mathrm{~m}^{-2}$, as opposed to Eurasian watermilfoil root crown of $39 \mathrm{~g} \mathrm{~m}^{-2}$. Therefore, total carbohydrate storage is $8.3 \mathrm{~g} \mathrm{~m}^{-2}$ for water celery, and $9.8 \mathrm{~g} \mathrm{~m}^{-2}$ for Eurasian watermilfoil root crowns. If the evergreen shoots which also store carbohydrates are included, total Eurasian watermilfoil overwintering biomass is $54 \mathrm{~g} \mathrm{~m}^{-2}$ and TNC concentrations are $20 \%$, for a total carbohydrate storage of $10.8 \mathrm{~g} \mathrm{~m}^{-2}$ in Lake Wingra. Eurasian watermilfoil is not at a disadvantage in competing with this tuber-forming species by not having specialized winter buds or tubers, based solely on total mass of carbohydrates stored. However, specialized propagules may confer other advantages, such as greater resistance to environmental fluctuations, decreased maintenance respiration during overwintering, and interannual dormancy of the propagule (Madsen 1991).

Carbohydrate Low Points. A carbohydrate low point is defined as a seasonal minimum in stored carbohydrates. Carbohydrate low points occur when carbohydrate usage from storage equals carbohydrate production. The primary low point is that which occurs during spring regrowth, which is common for all temperate zone perennial plant populations. A secondary low point may occur before reallocation to storage components in the fall; not all populations will exhibit this. The secondary low point is not necessarily another minima, but often appears as the end of a low plateau in carbohydrate levels, before carbohydrates are reallocated to storage. Since root crowns are the primary overwintering storage site in Eurasian watermilfoil, minima in TNC levels in this tissue will indicate minima in whole-plant carbohydrate storage. For the Eurasian watermilfoil populations in the LAERF ponds, early-season minima occurred at different times each year (Figure 4), ranging from April (1992) to May (1993) and July (1991). In contrast, the secondary low point was consistently found in October of each year. Resumption of Eurasian watermilfoil growth in the fall may also be temperature-related. Autumnal weather patterns were more uniform between years than winter weather patterns, which may account for the similarities in secondary carbohydrate low points in the three years.

The occurrence of these seasonal low levels of carbohydrates for northern Eurasian watermilfoil populations can be compared to those of the Texas population using other published studies (Table 1), with populations having significantly different low points among years. In fact, different locations within a given lake can have significantly different timing of carbohydrate minima within a year, as noted in data for Lake Wingra (Titus and Adams 1979, Kimbel and Carpenter 1981).

None of the northern populations had secondary low points, including those shallow lakes that exhibited bimodal biomass growth curves (e.g., Lake Wingra; Table 1). The secondary low points characteristic of southern Eurasian watermilfoil populations may be related to higher water temperatures, which may be causing a mid-summer reduction in growth due to temperature stress and high dark respiration rates.

Information on carbohydrate storage may be useful in planning or evaluating the timing of control technique applications, and evaluating the results of these applications. Consideration of the timing of carbohydrate low points 

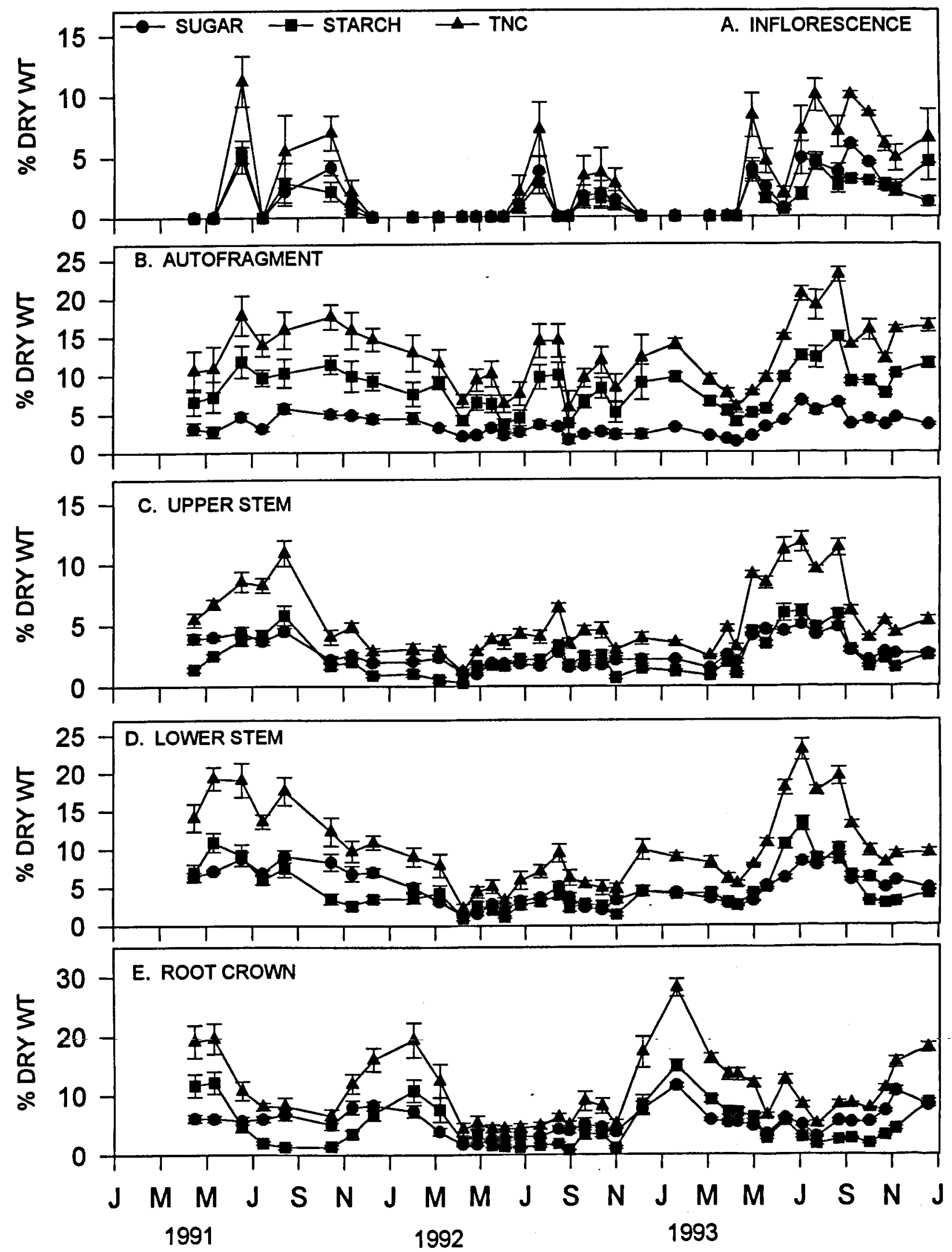

Figure 3. Eurasian watermilfoil plant component concentrations of free sugars (SUGAR), starch (STARCH), and total nonstructural carbohydrates (TNC) for experimental ponds in Lewisville, TX from 1991 to 1993; in percent of dry weight. A) Inflorescences, B) Autofragments, C) Upper stem, D) Lower stem, E) Root crown. Bars indicated \pm 1 standard error of the mean. 
TABLE 1. CARBOHYDRATE LOW POINTS IN THE SEASONAL GROWTH CYCLE OF EURASIAN WATERMILFOIL POPULATIONS FOR NORTHERN AND SOUTHERN POPULATIONS.

\begin{tabular}{|c|c|c|c|c|}
\hline Lake & State or Prov. & North or South & Date of Low Point & Reference \\
\hline Lewisville Pd & TX & $\mathbf{S}$ & $04-15-92$ & This Study \\
\hline Lewisville Pd & TX & $\mathbf{S}$ & $05-21-93$ & This Study \\
\hline Lk Wingra (A\&B) & WI & $\mathbf{N}$ & $05-30-75$ & Titus \& Adams 1979 \\
\hline Lk Wingra (C\&D) & WI & $\mathbf{N}$ & $05-30-76$ & Kimbel \& Carpenter 1981 \\
\hline Lk Washington & WA & $\mathbf{N}$ & $05-30-81$ & Perkins \& Sytsma 1987 \\
\hline Buckhorn Lk & ONT & $\mathbf{N}$ & $05-30-82$ & Painter 1988 \\
\hline L.k Wingra $(C \& D)$ & WI & $\mathbf{N}$ & $06-15-75$ & Kimbel \& Carpenter 1981 \\
\hline Buckhorn Lk & ONT & $\mathbf{N}$ & $06-15-79$ & Painter 1988 \\
\hline Buckhorn Lk & ONT & $\mathbf{N}$ & $06-15-80$ & Painter 1988 \\
\hline Buckhorn Lk & ONT & $\mathbf{N}$ & $06-15-81$ & Painter 1988 \\
\hline Buckhorn Lk & ONT & $\mathbf{N}$ & $07-15-83$ & Painter 1988 \\
\hline Buckhorn Lk & ONT & $\mathbf{N}$ & $07-15-84$ & Painter 1988 \\
\hline Lk Wingra (A\&B) & WI & $\mathbf{N}$ & $07-15-74$ & Titus \& Adams 1979 \\
\hline Lewisville Pd & TX & $\mathbf{S}$ & $07-15-91$ & This Study \\
\hline Lk Washington & WA & $\mathbf{N}$ & $07-30-80$ & Perkins \& Sytsma 1987 \\
\hline Lewisville Pd & $\mathbf{T X}$ & $\mathbf{S}$ & $10-04-93$ & This Study \\
\hline Lewisville Pd & TX & $\mathbf{S}$ & $10-15-91$ & This Study \\
\hline Lewisville Pd & TX & $\mathbf{S}$ & $10-30-92$ & This Study \\
\hline
\end{tabular}

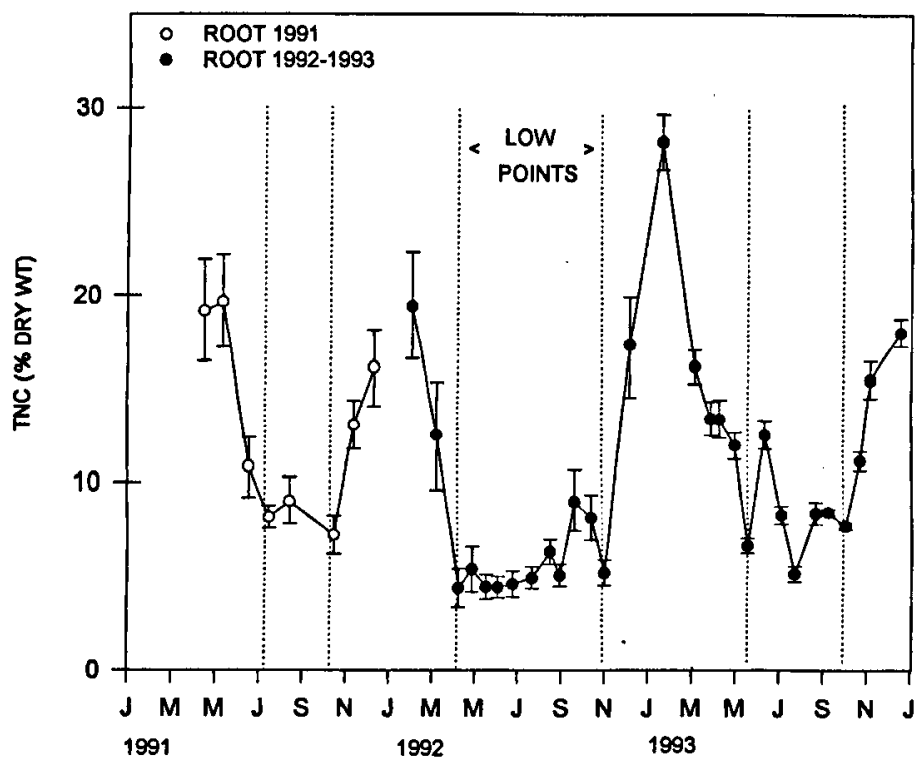

Figure 4. Eurasian watermilfoil root crown concentrations of total nonstructural carbohydrates (TNC) for experimental ponds in Lewisville, TX from 1991 to 1993; in percent of dry weight. Bars indicated \pm 1 standard error of the mean. Vertical dotted lines indicate the timing of primary and secondary low points of carbohydrate levels for each year.

might be particularly useful for management with harvesting and contact herbicides, where regrowth is a significant concern. However, carbohydrate storage is also important for understanding the success, or failure, of other management techniques.

\section{ACKNOWLEDGMENTS}

This research was conducted under the US Army Corps of Engineers Aquatic Plant Control Research Program, Environmental Laboratory, US Army Engineer Waterways Experiment Station (WES). Permission was granted by the Chief of Engineers to publish this information. Field assistance at LAERF was provided by Chetta Owens, Bekah Westover,
Nicole Flint, Brittany Glassie, Timothy Irby, Lovely John, Keith Lloyd, Dian Smith, Melissa Smith, and Nathan Standifer. Laboratory analyses were performed at WES by Jane Brazil, Margaret Richmond, Anne Stewart, and Dr. Susan Sprecher. Drs. Kurt Getsinger and Susan Sprecher provided comments and suggestions for this manuscript.

\section{LITERATURE CITED}

Adams, M. S. and M. D. McCracken. 1974. Seasonal production of the Myriophyllum component of the littoral of Lake Wingra, Wisconsin. J. Ecol. 62: 457-467.

Aiken, S. G., P. R. Newroth, and I. Wile. 1979. The biology of Canadian weeds. 34. Myriophyllum spicatum L. Can. J. Plant Sci. 59: 201-215.

Best, E. P. H. 1977. Seasonal changes in mineral and organic components of Ceratophyllum demersum and Elodea canadensis. Aquat. Bot. 3: 337-348.

Center, T. D. and T. K. Van. 1989. Alteration of waterhyacinth (Eichhornia crassipes (Mart.) Solms) leaf dynamics and phytochemistry by insect damage and plant density. Aquat. Bot. 35: 181-195.

Couch, R. and E. Nelson. 1985. Myriophyllum spicatum in North America. Proc. 1st International Symposium on watermilfoil (Myriophyllum spicatum) and related Haloragaceae species. Aquatic Plant Manage. Soc. p. 8-18.

Cyr, D. R., J. D. Bewley, and E. B. Dumbroff. 1990. Seasonal dynamics of carbohydrate and nitrogenous components in the roots of perennial weeds. Plant, Cell and Environ. 13: 359-365.

Engel, S. 1993. Status of Eurasian watermilfoil in Wisconsin. LakeLine 13(2): 10-13. June, 1993.

Gallagher, J. L., P. L. Wolf, and W. J. Pfeiffer. 1984. Rhizome and root growth rates and cycles in protein and carbohydrate concentrations in Georgia Spartina allerniflora Loisel. plants. Amer. J. Bot. 71: 165-169.

Garza, A., Jr., T. McClendon, and D. L. Drawe. 1994. Herbage yield, protein content, and carbohydrate reserves in gulf cordgrass (Spartina spartinae). J. Range Manage. 47: 16-21.

Grace, J. B. and R. G. Wetzel. 1978. The production biology of Eurasian watermilfoil (Myriophyllum spicatum L.): A review. J. Aquat. Plant Manage. 16: 1-11.

Hodgson, R. H. 1966. Growth and carbohydrate status of sago pondweed. Weeds 14: 263-268.

Kimbel, J. C. 1982. Factors influencing potential intralake colonization by Myriophyllum spicatum L. Aquat. Bot. 14: 295-307.

Kimbel, J. C. and S. R. Carpenter. 1981. Effects of mechanical harvesting on Myriophyllum spicalum $\mathrm{L}$. regrowth and carbohydrate allocation to roots and shoots. Aquat. Bot. 11: 121-127.

Klingman, G. C., F. M. Ashton, and L. J. Noordhoff. 1975. Weed Sciences: Principles and Practices. John Wiley, New York.

Madsen, J. D. 1991. Resource allocation at the individual plant level. Aquat. Bot. 41: 67-86. 
Madsen, J. D., L. W. Eichler, and C. W. Boylen. 1988. Vegetative spread of Eurasian watermilfoil in Lake George, New York. J. Aquat. Plant Manage. 26: 47-50.

Madsen, J. D., J. W. Sutherland, J. A. Bloomfield, L. W. Eichler, and C. W. Boylen. 1991. The decline of native vegetation under dense Eurasian watermilfoil canopies. J. Aquat. Plant Manage. 29: 9499.

McAllister, R. S. and L. C. Haderlie. 1985. Seasonal variations in Canada Thistle (Cirsium arvense) root bud growth and root carbohydrate reserves. Weed Sci. 33: 44-49.

Nelson, N. 1944. A photometric adaptation of the Somogyi method for determination of glucose. J. Biol. Chem. 153: 375-380.

Painter, D. S. 1988. Long-term effects of mechanical harvesting on Eurasian watermilfoil. J. Aquat. Plant Manage. 26: 25-29.

Painter, D. S. and J. I. Waltho. 1985. Short-term impact of harvesting of Eurasian watermilfoil. Proc. 1st International Symposium on watermilfoil (Myriophyllum spicatum) and related Haloragaceae species. Aquatic Plant Manage. Soc. p. 187-201.

Patten, B. C. 1956. Notes on the biology of Myriophyllum spicatum in a New Jersey lake. Bull Torrey Bot. Club 83: 5-18.

Perkins, M. A. and M. D. Sytsma. 1987. Harvesting and carbohydrate accumulation in Eurasian watermilfoil. J. Aquat. Plant Manage. 25: 57-62.
Schirman, R. and K. P. Buchholtz. 1966. Influence of atrazine on control and rhizome carbohydrate reserves of quackgrass. Weeds 14: 233-236.

Smart, R. M., G. O. Dick, D. R. Honnell, J. D. Madsen, and J. R. Snow. 1995. Physical and environmental characteristics of experimental ponds at the Lewisville Aquatic Ecosystem Research Facility, US Army Engineer Waterways Experiment Station Misc. Paper A-95-2, Vicksburg, MS.

Smith, C. S. and J. W. Barko. 1990. Ecology of Eurasian watermilfoil. J. Aquat. Plant Manage. 28: 55-64.

Swank, J. C., F. E. Below, R. J. Lamber, and R. H. Hageman. 1982. Interaction of carbon and nitrogen metabolism in the productivity of maize. Plant Physiol. 70: 1185-1190.

Titus, J. E. and M. S. Adams. 1979. Comparative carbohydrate storage and utilization patterns in the submersed macrophytes, Myriophyllum spicatum and Vallisneria americana. Amer. Midl. Nat. 102: 263-272.

Tucker, C. S. and T. A. DeBusk. 1981. Seasonal growth of Eichhornia crassipes (Mart.) Solms: Relationship to protein, fiber, and available carbohydrate content. Aquat. Bot. 11: 137-141.

Weldon, L. W. and R. D. Blackburn. 1968. Herbicidal treatment effect on carbohydrate levels of alligatorweed. Weed Sci. 16: 66-69.

Winston, R. D. and P. R. Gorham. 1979. Turion and dormancy states in Utricularia vulgaris. Can. J. Bot. 57: 2740-2749. 


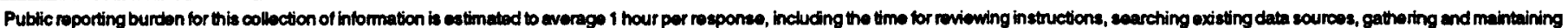

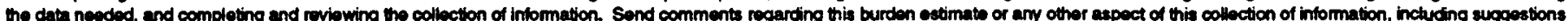

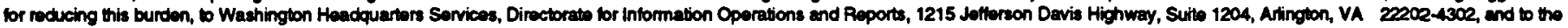
Office of Management and Budget, Papenwork Rectuction Project (0704-0188), Washington, DC 20503.

\begin{tabular}{|l|l|l|}
\hline 1. AGENCY USE ONLY (Leave blank) & $\begin{array}{c}\text { 2. } \\
\text { REPORT DATE } \\
\text { June } 1997\end{array}$ & $\begin{array}{l}\text { 3. REPORT TYPE AND DATES COVERED } \\
\text { Final report }\end{array}$ \\
\hline
\end{tabular}

4. TITLE AND SUBTITLE

Seasonal Biomass and Carbohydrate Allocation in a Southern Population of

5. FUNDING NUMBERS

Eurasian Watermilfoil

6. AUTHOR(S)

John D. Madsen

7. PERFORMING ORGANIZATION NAME(S) AND ADDRESS(ES)

U.S. Army Engineer Waterways Experiment Station

3909 Halls Ferry Road

Vicksburg, MS 39180-6199

8. PERFORMING ORGANIZATION REPORT NUMBER

Miscellaneous Paper A-97-4

9. SPONSORINGMONTORING AGENCY NAME(S) AND ADDRESS(ES)

U.S. Army Corps of Engineers

10. SPONSORINGMONITORING

Washington, DC 20314-1000

AGENCY REPORT NUMBER

\section{SUPPLEMENTARY NOTES}

Available from National Technical Information Service, 5285 Port Royal Road, Springfield, VA 22161.

12a. DISTRIBUTIONAVALLABILTY STATEMENT

Approved for public release; distribution is unlimited.

12b. DISTRIBUTION CODE

13. ABSTRACT (Maximum 200 words)

Seasonal biomass and carbohydrate allocation patterns of Eurasian watermilfoil (Myriophyllum spicatum L.) were evaluated to elucidate potential points in the seasonal phenological cycle for improved control. Eurasian watermilfoil was sampled from outdoor 0.3-ha ponds in Lewisville, TX, from January 1991 to December 1993 and analyzed for free sugars, starch, and total nonstructural carbohydrates (TNC). Root crowns stored up to 30-percent TNC, followed by autofragments (25 percent), lower stems (22 percent), and upper stems and inflorescences ( 12 percent). Low levels of stored carbohydrates occurred in July 1991, April 1992, and May 1993. Low levels of stored carbohydrates also were observed in October for all 3 years. Low points in carbohydrate storage might be exploited to improve management of Eurasian watermilfoil.

\begin{tabular}{|c|c|c|c|}
\hline 14. & $\begin{array}{l}\text { SUBJECT TERMS } \\
\text { Autofragment } \\
\text { Inflorescence } \\
\text { Myriophyllum spicatum }\end{array}$ & & $\begin{array}{l}\text { Phenology } \\
\text { Starch } \\
\text { Total nonstructural carbo }\end{array}$ \\
\hline 17. & $\begin{array}{l}\text { SECURTY CLASSIFICATION } \\
\text { OF REPORT } \\
\text { UNCLASSIFIED }\end{array}$ & 18. & $\begin{array}{l}\text { SECURITY CLASSIFICATION } \\
\text { OF THIS PAGE } \\
\text { UNCLASSIFIED }\end{array}$ \\
\hline
\end{tabular}

NSN 7540-01-280-5500
15. NUMBER OF PAGES

13

16. PRICE CODE 